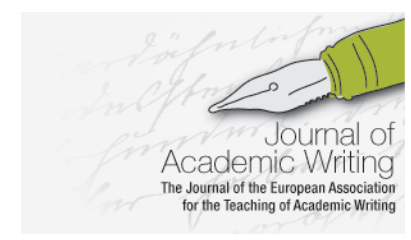

Journal of Academic Writing

Vol. 8 No 1 Summer 2018, pages 1-12

http://dx.doi.org/10.18552/joaw.v8i1.397

\title{
A Framing Analysis of the Treatment of Creativity as a Topic or Goal in German Books on Research Writing
}

Ingo Peters

Chulalongkorn University, Thailand

\begin{abstract}
Many students in Germany undertaking academic writing tasks consult one of the numerous German-language books on research writing. Curiously, these works tend to downplay or ignore creativity, compared to their American counterparts. A hermeneutic and rhetorical study that examines the structure, content, and style of 21 German books on research writing with the help of framing theory reveals that, firstly, the rationale given to readers for learning how to do a research project is usually that it enables them to complete difficult tasks and thus to graduate successfully - the potentially fascinating aspects, such as learning through writing, and the possibility of advancing the field are rarely mentioned. Secondly, when defining good academic research, US books stress exploration and invention based on wrestling with questions, while the German ones mostly emphasize rules, correctness within a fixed system, and the mastery of techniques. Finally, in the 21 works, academic work primarily comes across as a solitary, linear process neatly divided into separate phases, not as a holistic, discursive practice that takes place within the research community. The likely reasons for this phenomenon highlight several crucial challenges German writing teachers and consultants are facing: as the rhetoric/composition and writing consultancy scene in Germany is vibrant but somewhat marginalized at universities and relatively new, there is no tradition of mandatory composition courses influenced by writing studies with a creative component, and most guidebooks on research are not by writing experts but by professors in other fields. Moreover, there is still widespread belief that creativity cannot be taught, and that students' fascination with their chosen field of study should be taken for granted, so that neither need to be mentioned in primers. Terminology might also play a role; the German term for 'research (writing)', 'Wissenschaftliches Arbeiten' or 'academic practice', already appears to emphasize correctness over discovery.
\end{abstract}

\section{Introduction}

In recent years, the thinking about research writing in Germany has undergone a paradigm shift: students' ability to compose successful academic texts is not taken for granted anymore at the university level; instead, writers and teachers understand it as something that needs to be taught and reflected on, as a difficult skill that is only gradually acquired in college (Schindler and Fischbach 2015). To help the students on this voyage, there are now a plethora of guidebooks (Schindler 2008: 2), just like in the US, the country where the explicit teaching of academic writing has the longest tradition.

However, as a native speaker of German who teaches writing and research in an Englishspeaking context and thus consults and uses both German and English-language books, I noticed fundamental differences in emphasis between the publications from the US and those from Germany - differences that go beyond the known contrasts between the academic writing styles of the two cultures that, for example, Clyne (1987) analyzed. One particularly important and surprising peculiarity of the German works that merits a close examination is the lack of 
focus on creativity: I contend that in German textbooks and guidebooks on research and research writing, most of the things that could be subsumed under the umbrella term 'creativity' tend to be downplayed or play a relatively minor role.

Now, the term creativity is notoriously difficult to define, and indeed some theories are contradictory (Ripple 1999: 630). However, what many scholars can agree on is that something is creative if it involves both 'originality' or 'novelty', and 'utility' or 'usefulness' (Simonton 2013: 69). In other words, creative acts are ventures into the unknown, fueled by curiosity, which actually benefit someone by solving a problem or improving a situation. The latter implies that creativity requires a discourse community that is made aware of the act and judges it; in fact, Csikszentmihalyi explicitly made the 'field of experts who recognize and validate the innovation' (1996: 6) the third necessary criterion of his creativity definition. In a similar vein, Robert E. Franken linked creativity to three areas: problem-solving, novel and complex stimulation, and communication with others (1993: 396). It is significant that American research writing books tend to share this sense of creativity, as they portray the desire to solve a problem as the rationale for doing research, curiosity as a much needed quality for good researchers, and communication as their central method. The works from Germany, on the other hand, appear to replace these concepts with the desire to graduate, the ability to follow rules, and the solitary nature of research.

I will support this thesis via an analysis of 21 of the most popular German guidebooks on academic writing and research. Given the large number of primers, I concentrate on the general ones, omitting the many aimed at specific disciplines, such as economics. Some of the betterknown titles are not brand new, and together with the fast growth of the genre, this means that I cannot claim that the study fully represents the current state of, or the absolute latest trends in, the guidebook market. As for method, instead of employing a quantitative approach, I will look at the works through rhetorical and hermeneutic lenses, focusing on the content, structure and style of the texts. The theoretical approach that I embed these analyses in is framing theory; basically, it can be claimed that the patterns of omission and emphasis suggest that as a whole, the issue of research writing in Germany is framed, consciously or unconsciously, as not being very dependent on or related to creativity. I will isolate three specific frames that highlight and illustrate this.

\section{Framing Theory as a Tool for Rhetorical Analysis}

To clarify the nature and usefulness of framing analysis in terms of this study on research writing, it is essential to first explain framing and frames in more detail. Kuypers gives the following definition: 'Framing is a process whereby communicators, consciously or unconsciously, act to construct a point of view that encourages the facts of a given situation to be interpreted by others in a particular manner [...] Frames are often found within a narrative account of an issue or event, and are generally the central organizing idea' (2006: 7).

In other words, how information is presented to the audience influences how people process that information. As the classic 1993 definition by Robert Entman phrased it, "[t]o frame is to select some aspects of a perceived reality and make them more salient [meaning, more noticeable, meaningful and memorable] in a communicating text, in such a way as to promote a particular problem definition, causal interpretation, moral evaluation, and/or treatment recommendation for the item described' (52).

As an example, Entman discusses the 'cold war' frame that dominated the discourse about foreign affairs in the US in the 1970s and 1980s (1993: 52). The cold war frame highlighted certain events (like civil wars) as problems, purported to explain the causes (e.g. communist rebels), and offered both moral judgment (atheist aggression) and solutions (US support for the other side). In another example, Entman shows that opinions about AIDS testing change depending on if the debate is framed as a civil liberty issue or in public health terms (1993: 55). According to Entman, frames 'exert their power through selective description and omission [emphasis, elaboration, exclusion, etc.] of the features of a situation' (1993: 54), and this power 
is considerable. Indeed, Michael J. Carter, paraphrasing Stuart Hall (1982), stresses that 'if an event is initially framed in a context, then any future information regarding that event will be understood in the way it was initially framed' (Carter 2013: 3).

Framing is both subtler and stronger than persuasion: Nelson, Oxley and Clawson reveal, through empirical studies, that 'unlike standard persuasion models, framing effects do not depend upon the recipient's acceptance of the message's assertions [...] more- and lesssophisticated subjects do not differ in their comprehension of framed messages' (1997: 228). In other words, it is hard to counter frames with critical thinking. The effect is strongest if the frame is very persistent throughout many texts and works, because then routinization sets in, as Stephen Reese maintains: 'Routinization suggests that a frame has a second-nature, well entrenched, and built into the way of doing things' (2001: 15). It can be shown that, in fact, such frames that get repeated again and again are present throughout the 21 German research writing books, so that what they affirm has indeed become entrenched and routinized within the community of readers.

\section{Frame 1: The Rationale for Pursuing Research Projects}

The first frame has to do with the rationale for doing research and consulting a book on how to learn it. The frame is concerned with the 'need' or 'justification' issue - how the works present the reasons why students should pursue a research project, learn how to write academically, and read up on it. If one looks at the 21 works together as a whole, the impression that one gets is that research (and with it, research writing) is framed as a 'necessary evil', a duty or obligation - something that the student just needs to get done. To be precise, research projects appear as, first, unpleasant; second, without benefits; and third, as isolated one-time tasks, rather unrelated to the perhaps positive experience of studying and learning and growing. In fact, research tasks are presented more like interruptions of this experience.

Balzert et al. serve as a representative example, and their rhetoric illustrates some of the abovementioned features. They write: 'From a dissertation to a term paper, rules have to be followed [...] Here, it is not only about academic texts that have to be composed correctly and mastered as a self-contained project' (,Von der Dissertation bis zur Hausarbeit sind Regeln zu beachten [...] Dabei müssen nicht nur wissenschaftliche Texte formal korrekt angefertigt und als eigenständiges Projekt beherrscht werden' (2008: V)). This passage actually constitutes the opening of the book; it is the second sentence of the preface, so it sets the tone for the whole work. Of course the authors are technically not wrong - the categories of 'right' or 'wrong' are not particularly helpful for framing analyses - but one can clearly see research writing being recast as an obligation. The verb 'have to' or 'must' shows up a lot, emphasizing the duty of the researchers; the passive voice does not suggest that they have room for creative input here. The project does not seem fascinating or an opportunity. Krämer's focus and language follow the same pattern: in his second sentence, he declares that his tome is intended for students who 'have to hand in theses or term papers' (die Bachelor-, Master-, Seminar- und Diplomarbeiten [...] abzuliefern haben' (2009: 11)). Peterßen, also in his second sentence, wishes to 'help all those who have to write academic papers' (,all jenen Hilfestellung geben, die wissenschaftliche Arbeiten anfertigen müssen' (1999: 11)), and the title of his introduction can be translated as 'Research Papers: A Curricular Requirement' (,Wissenschaftliches Arbeiten: Eine Forderung in Prüfungs-, Studienordnungen und Lehrplänen' (1999: 15)). Preißner calls papers an 'exasperating compulsory exercise' (,leidige Pflichtübung') on his first page (2012: 1). Most of the works open with this obligation idea - that students do research because they have to, not for other reasons - in some form, and it cannot be completely insignificant that the guides contain this rationale for learning how to write, and not others.

Some books assume an actively hostile or panicked stance of the students towards research: Charbel begins her book by writing, 'Every student who has ever tackled any sort of dissertation or thesis will also know this feeling of panic that creeps in sooner or later [...] Help!' (,jeder, der eine Diplomarbeit (oder Magister- oder Examensarbeit) in Angriff nimmt, kennt auch dieses Gefühl von Panik, das sich früher oder später einschleicht [...] Hilfe!' (2006: 7)). Haines writes in her preface that the 'extreme situation' (,Extremsituation') of having to write a long paper produces such 'time pressure and pressure to succeed' (,Zeit- und Erfolgsdruck') that students are 'hardly able to assess how useful the various available guide books are' (,kaum noch 
imstande, die verschiedenen Ratgeber auf ihre Tauglichkeit zu überprüfen' (2009: 5)). Esselborn-Krumbiegel asks her readers: 'What comes into your mind when you hear the words "academic writing"?' (,Woran denken Sie, wenn Sie "wissenschaftlich schreiben" hören?'), and presumes the answers will include 'anger', 'frustration', 'chaos', and 'stress' (,Wut', ,Frust', 'Chaos', ,Stress' (2002: 7)). Even Pyerin's creative-writing primer opens with 'threatening piles of books', 'fear', and the 'thicket of complex rules' (,bedrohlichen Bücherstapel', ,Angst', ,Dickicht von komplizierten Regeln' (2001: 9)). Plenty of the authors expect such a negative attitude from their readers towards research papers that they define their own unique selling point as making the process quick and easy, which is often reflected in the titles: Kornmeier's work (2008) is called 'Academic Writing Made Easy' (,Wissenschaftlich Schreiben leicht gemacht'), Charbel's (2006) is called 'Fast and Easy to Your Dissertation: The Practical Guidebook' (,Schnell und einfach zur Diplomarbeit: Der praktische Ratgeber'). Heimes, in her first paragraph, similarly assures the readers that her book will allow them 'to write their paper in a manner that is as easy and pleasant as possible' (,Ihre Arbeit möglichst leicht und angenehm zu schreiben' (2011: 9)).

One of the reasons why this is significant is the fact that if a task is classified as thankfully quick and easy, this implies that the task in itself is something that the agent just wants to get finished, that he or she wants to be done and over with; the task in itself does not seem to be of much value. Even a seemingly innocuous title like Stickel-Wolf and Wolf's (2013) 'Academic Practice and Learning Techniques: Studying Successfully - The Know-How!' (,Wissenschaftliches Arbeiten und Lerntechniken: Erfolgreich studieren - gewusst wie!') frames research in that way: what seems to be essential is "success" in terms of doing well on assignments, with the help of clever "life hacks". What is regularly omitted is any discussion of why such writing and research assignments are there in the first place, and why it might make sense to have them.

American works, by contrast, not only often stress research as something positive and fascinating, but also as beneficial in a way that goes beyond grades or getting degrees, for example by showing how you can learn through writing. Ballenger opens by encouraging his readers to 'think through writing rather than before' (2012: 1); Arnold, Poston and Witek promise that their readers will be 'discovering multiple perspectives' (1999:12); and Roberts even advertises the dissertation as 'a peak experience - one of those life-fulfilling moments' (2010: 3). Guidebooks from the US also tend to discuss how the writers, by becoming a part of the research community, can actually advance their field and make 'an original contribution' (Roberts 2010: 18); at the very least they can claim to have found an 'entrance into the conversations of the discipline' (Clark 2007: 47). In the German works, only Preißner (2012: 169) devotes a lot of space to the uses of research, in his case in terms of benefits for future jobs.

Also largely omitted, with the exception of Kornmeier (2008), is the sense that research is not only a natural and integral part of any course of study at the university level, but the very heart, essence, main product and raison d'être of academia, something that, again, many American books frame their rationales with. Booth, Colomb and Williams implore the reader that without reliable research, 'we would be prisoners of what we alone see and hear, locked in the opinions of the moment' (1995: 7). Instead of talking about research in such a way, the German books tend to focus, already in the titles, on the singular research project as an isolated one-time task. Books are rarely about research or research writing in itself but about 'successfully' submitting 'Term Paper, Doctoral Dissertation, Masters Thesis' (,Seminararbeit, Doktorarbeit, Diplomarbeit'), as in Brauner and Vollmer (2004), about 'How Do I Write a Term Paper or Thesis?' (,Wie schreibe ich eine Seminar- oder Examensarbeit?'), as in Krämer (2009), about the 'Thesis ABC' (,ABC der wissenschaftlichen Abschlussarbeit'), as in Haines (2009), or about, as in Krajewskis's subtitle (2013), how to get to the 'Academic Dissertation in Seven Steps' (,Zur wissenschaftlichen Abschlussarbeit in 7 Schritten'). Technical, utilitarian metaphors used to illustrate the process, from planning to revising, strengthen the impression that research projects are independent one-time tasks, not integrated parts of a larger whole: Heimes compares the paper to 'building a house' (,Hausbau') and vows to provide a 'construction manual' (,Bauanleitung' (2009: 9)), while Kornmeier's metaphor is a 'ring cake' (,Gugelhupf' (2008: 15)). In this regard, it is significant that what a cake and a house have in common is that they are ends in themselves, not linked to anything outside themselves. Once they are done, 
they are done. So again, overall research writing projects are framed, even if unintentionally, as obligations that are carried out because one was assigned to do so, not for their benefits, not for their role in one's academic growth and the field, and not due to one's curiosity and fascination.

\section{Frame 2: The Definition of Good Research}

The second frame has to do not with the reasons for doing research but with the definition of research or good research. It is concerned with questions such as, what is research writing, what matters for research, or what are the highest values for a writer and researcher. In this context, I believe it can be said that in the German books, research writing tends to be framed - again, perhaps unintentionally - in terms of rules, standards, and techniques. A proper researcher appears to be the one who is correct within a fixed system, and has mastered techniques, rules and standards.

Brauner and Vollmer's very first chapter, for example, is devoted to defining academic papers or academic work. It does so by listing, in a chart and in writing, 'criteria' (,Kriterien') that have to be fulfilled to make the work academic, for instance, 'theoretical foundation', (,theroretische Grundlage'), 'critical engagement with sources', (,kritische Auseinandersetzung mit der Literatur'), 'representativeness' (,Allgemeingültigkeit') and 'originality' (,Neuigkeitsgehalt' (2004: 14-17)). This not only implies that research and scholarly work equals assignments/products, but it is also mechanistic and it rhetorically suggests that sticking to rules, to a kind of academic checklist, is the starting point for and key to research. Balzert et al. even make this explicit: their first chapter begins with the statement, 'Of primary importance for the quality of academic work is the adherence to internationally accepted rules and quality criteria' (,Grundlegend wichtig für die Qualität wissenschaftlicher Arbeit ist die Beachtung international anerkannter Spielregeln und Qualitätskriterien' (2008: 3)). The first forty pages again define ,Wissenschaftlichkeit' or 'What being academic means' via ten criteria, such as 'objectivity' (,Objektivität') or 'validity' (,Validität' (2008: 5-40)). Winter similarly opens with the 'core requirements for academic papers' (,Kernanforderungen an wissenschaftliche Arbeiten' (2005: 6)). Krämer also begins with three rules, which he helpfully spells out as rule no. 1, rule no. 2 , and rule no. 3 (,Regel Nr. $1^{1}$, ,Regel Nr. 2', ,Regel Nr. 3' (2009: 13-14)). The fact that he later adds that academic writers are in fact allowed to have fun (,Und Spaß machen darf das alles auch' (2009:15)) does not change the impression that research is framed as primarily being about not violating the rules of a fixed system. Krajewski uses algorithm metaphors to stress this, emphasizing that the researcher proceeds 'like a computer' (,Ähnlich einem Computer' (2013: 9)).

In contrast, in US books, research writing is often defined and framed in the exact opposite way (even if the actual content is not that different): it is defined in terms of its openness. Research is frequently likened to a journey, or to discovery, and thus to creativity, invention, activity and exploration (note typical titles like Making Sense, The Curious Researcher, or The Dissertation Journey). When Ballenger entitles his preface 'Placing Inquiry at the Heart of the Course' and claims that 'research writing is a very creative enterprise' (2012: xxiii), he basically expresses American consensus. Part of this US frame is the extreme focus on the research question as the central part of any research project (e.g. in Booth, Colomb and Williams 1995: 29-72) - a question is by definition still unanswered, you have to enter unexplored territory, and if your main task beforehand is finding this question in the first place, it is even more of a discovery.

In the German books, the research question does not get this special treatment. The focus is much more on the topic. There is a difference. With a topic, rather than having to go out and find answers, one can write about things one already knows. Of the 21 works, 19 mention the topic in the table of contents, often very prominently as a chapter of its own, but only six mention the question, often as a sub-idea of the topic choice. The case of Pospiech (2012) is typical of the way the research question is brought up, if it is actually brought up at all. She writes: 'To plan a term paper, it is necessary [...] to examine the current state of the research on a topic, to delineate the topic, and to devise a question that is appropriate for one's research interest' (,Um eine Seminararbeit zu erarbeiten, gilt es [...] die Forschungslage zu einem Fachgebiet zu sichten, das Thema einzugrenzen und eine dem Erkenntnisinteresse angemessene Fragestellung zu entwickeln' (2012: 16)). The question here is one step among many, not the pivot and engine of the research process, and it appears like an automatism, not something 
that needs creativity. Peterßen's (1999) rhetoric makes this even clearer. He writes : 'It is possible/advisable to transform the topic into a question or thesis' (,Es bietet sich an, das Thema in eine Frage oder These zu übersetzen' (1999: 44)). This phrasing suggests, first, that the question is just an option, not essential like the topic. And second, it implies that arriving at a question is easy, mechanistic and a mere formality once the topic is clear.

Thus, the topic or Thema dominates in the German discourse. And in the books, the topic tends to be not found, via creative exploration, but given. Haines (2009: 20) and Heimes (2011: 17) both use the term ,Aufgabenstellung', or, roughly, 'research assignment', which implies passivity on the researchers' part, as a set topic is waiting for them. Brauner and Vollmer talk about finding a topic but take the creativity out of the process by again covering it with a list of rules (2004: 23).

Interestingly, when the authors do address the freedom of students to choose topics of their own, this does not turn into discovery either. Here, the discourse is very much about the researcher him- or herself and what he or she already knows, not about gaps in the current research, leaving one's state of knowledge behind, and exploring. Krämer advises the reader to answer the following self-involved questions: 'What am I especially good at? [...] Whom [...] do I want to impress with my work?' (,Was kann ich besonders gut? [...] Wen [...] will ich mit der Arbeit beeindrucken?' (2009: 17)). Haines similarly stresses, under the heading 'The Beginning' (,Anfangen'), that the starting point must be 'what the potential author of the paper is familiar with' (,wo und womit sich der potenzielle Verfasser dieser Arbeit auskennt' (2009: 17)). Heimes, too, puts 'my interests in terms of theory and practice' (,Mein Erkenntnis- und Praxisinteresse') front and center (2011: 12).

Overall, research writing is indeed framed not as a journey into the unknown, but as being about moving within well-defined boundaries and sticking to rules. Even with Esselborn-Krumbiegel (2002), who has a very good write-up of the research question and emphasizes the journey idea, the chosen metaphor for the terra incognita, ,Forschungsdschungel' or 'research jungle' (2002: 69), sounds hostile in German, like something that is hard to navigate and threatening. Kornmeier (2008), who also writes well about the research question, explicitly and repeatedly warns against stressing creativity too much: 'Academic writing is not primarily a question of creativity' (,wissenschaftliches Schreiben ist nicht in erster Linie eine Frage der Kreativität' (2002: 16)). Likewise, Göttert feels forced to criticize the 'current studying environment' (,augenblickliche Lernmilieu') for valuing 'creativity more than adhering to norms' (eher ,Kreativität als Normbefolgung' (1999: 7-8)).

\section{Frame 3: The Research Process and the Research Community}

The third frame has to do with the nature of the research process and who is involved in it. Most American books frame the process as a discursive one that takes place within the research community. They follow the famous analogy of Kenneth Burke, who likened the research process to a conversation at a party - you arrive when the discussion is already in full swing, you listen, participate, and when you leave, the conversation is not over (1974: 110-111). It is no accident that not one, but two US books have the phrase 'Entering the Conversation' in the title (Goshert 2009; Clark 2007), or that one of the most popular works is called They Say/l Say (Graff, Birkenstein and Durst 2014). The German books, however, tend to depict the process as a linear, solitary activity. They do not reflect the fact that research is becoming more and more of a collaborative endeavor (Swales and Feak 2012: vii). Projects do not come across as contributions to a larger debate, as reactions to other researchers which in turn await those researchers' replies. In fact, the research or discourse community is hardly ever mentioned; only one of the 21 books includes the concept in the table of contents (Kruse 2007: 5). Preißner actively downplays the idea that one's work could matter to others on page 1: 'By the way, the content of the dissertation is rarely talked about afterwards' (,Über die Inhalte der Arbeit redet man übrigens meist nicht mehr' (2012)).

When the research community does get mentioned, it is not to highlight its status as the prime cause and locus of academic research projects, but for rather surprising minor reasons. Esselborn-Krumbiegel is one of the few who explicitly refer to the concept of the 'Scientific Community' and evoke a 'dialogue with the existing literature on the one hand and your potential 
readers on the other' (,ein Dialog mit der Forschung einerseits und mit Ihren potenziellen Lesern andererseits' (2002: 9)). She brings these ideas up in the part that attempts to minimize the research writer's anxiety: They will allow him or her to 'speak clearly instead of timidly and in a low voice' (,Damit Ihre Stimme klar und deutlich zu hören ist statt ängstlich und leise' (2002: 9)). The practical sections that actually focus on the business of, for example, getting from ideas to research questions paint the picture of the solitary thinker again (2002: 35). Of the eight strategies that are discussed, seven are highly technical ones like clustering or mind-mapping, which creates the impression that the process is not about listening to others but about listening to oneself.

This is typical. Charbel's write-up about the topic search (2006: 30-35) implies that the only other people that influence the research process are the supervisor and potential supporters. Both are mentioned for tactical reasons. The former has to be chosen smartly, as 'he [sic] will probably roundly reject proposals from areas that he is not familiar with' (,Arbeiten aus ihm nicht vertrauten Gebieten wird er vermutlich von vornherein ablehnen' (2006: 32)). The latter 'companies', 'agencies' but also uncles who might be writers (,Firmen', ,Behörden', ,Vielleicht war Ihr Onkel ein Schriftsteller') - serve as convenient sources of information (2006: 34). Researchers working on the topic do not come up, and neither do debates. Instead, and this is highly interesting, Charbel, like many of the German writers, talks about ,Vorwissen' (2006: 33) and the importance of taking the same into account. 'Vorwissen' translates as 'prior knowledge' in the sense of 'my own personal prior knowledge', so although the knowledge had by nature to be gained from publications others wrote, the wording erases the community and further frames the research process as individualistic. Similarly, Krajewski uses a phrase for finding out what others have written that is decidedly impersonal, almost to the point of caricature: ,Klärung der Materiallage' (2013: 21). Literally meaning 'clarification of the situation regarding the material', the term brings to mind a bureaucrat (or a machine) going through forms. Winter's turn of phrase for the chapter title on early stages of the research that engage with sources, ,Theoretischer Bezugsrahmen' ('theoretical conceptual framework' (2005: 57)), does the same. The concepts of dialogue, debate or exchange will not be entertained by any reader in such a context.

Thus, inherent in the German books is a rhetorical and topical transformation of the research community, which is made up of people, into things the lone researcher works with, and therefore of discourse into solitary thought. The transformation works in at least two ways. On the one hand, instead of talking about engaging with the findings of others, the books talk about catalogs, bibliographies, reference works (Haines 2009: 130) - tools, in short - or abstract entities like 'the public' (,Öffentlichkeit') 'research' (,Forschung') or 'academia/academic teaching' (,Hochschullehre'), which Voss lists as outside sources to find topics, but not as groups one is already a part of (2010: 41-45). On the other hand, actual people, as seen above, are taken out of the primary research process and relegated to the sidelines: as, in Krajewski, friends to sometimes leisurely bounce ideas off (,Nicht selten allerdings entstehen tragfähige Ideen [...] im zwanglosen Gespräch mit Kommilitonen und Freunden' (2013: 17)), or, in Haines, as supervisors whose permission has to be secured (,ist es angeraten, den Kontakt zu seinem fachlichen Mentor, seinem Professor und Betreuer zu suchen, um sein Einverständnis [...] einzuholen' (2009: 130)). All in all, the core of research writing is framed as an individual practice to such a degree that standard ideas like 'entering the conversation' or 'they say/l say' are absent for the average reader.

\section{Conclusion}

It seems justified to claim that German books on research writing tend to ignore or downplay creativity, given that they frame sticking to rules as good research, solitary scholars as good researchers, and wanting to pass as a good reason for doing research. I do not wish to comment in detail on the question of whether these frames are a problem - that would be a topic for a different paper. (And this essay is certainly not trying to argue that the books are bad per se.) Nevertheless, the issue deserves a slightly speculative conclusion or coda about the 
possible causes for the difference in frames between Germany and the US. This might in turn highlight some challenges German writing teachers and consultants are facing.

One reason for the difference might be that in US colleges, writing is institutionalized in freshman composition, i.e. mandatory general writing courses, and those are run by departments or centers keenly aware of research that stresses the centrality of invention and audience-orientation. In the US, Rhetoric and Composition was conceived of early on as a 'teaching subject' (Harris 1997): what it studied was the teaching of writing, and what it taught was writing. Given this mission, it is natural that classes and assignments in first-year composition, as well as the primers that were often meant to accompany them, would focus on creative inquiry and other key concepts from writing studies. In contrast, in Germany, the guidebooks are for people who are already writing in their discipline. Students often don't 'learn' to write, at least not in mandatory classes (Siepmann 2006).

Secondly, perhaps terminology plays a role. For what Americans label research or research writing, Germans do not really use the equivalent 'Forschung' - not many guidebooks contain this word within their title. Instead, the most common term is 'Wissenschaftliches Arbeiten', which roughly translates as 'academic practice', 'academic best practices', or 'scholarly work'. That term already emphasizes discovery far less than the term 'research' does, which comes from the Old French 'recerche' and is associated with a 'diligent search' (Skeat 1893: 504). 'Wissenschaftliches Arbeiten' evokes correctness far more.

Finally, the fields of rhetoric, writing consultancy, and writing centers are very vibrant in Germany (Lahm 2016: 29), but they are a relatively new and not always well funded phenomenon (Schindler 2008), and much of their work is not that well known or not integrated institutionally that well (Lahm 2016: 33). Most of the 21 books analyzed in this article are actually not written by experts on writing, be they from those centers or elsewhere - in fact, the writing component of papers and dissertations receive less space in the books than in the American ones. It is notable in this respect that there are a few books by writing experts - most prominently Otto Kruse, one of the Godfathers of rhetoric/composition in German-speaking countries, but also Judith Wolfsberger, Andrea Frank, Stefanie Haacke, and Swantje Lahm which completely go against the frames that I point out. Kruse has a focus on fascination, on journeys, on questions, on the 'discourse community'/,Diskursgemeinschaft' (2007: 63), and is very close to the American framing. Since his book is relatively old (the first edition came out in 1993), and it is very well known among writing teachers and consultants, it is surprising that neither it nor the later contributions by Wolfsberger (2007) and Frank, Haacke, and Lahm (2007) seem to have had much impact on the guidebooks that came afterward. The simplest explanation for this would be that, as stated above, the authors did not look much into the field of rhetoric and composition. Apart from this, there is also the German historical tradition of having university students generate meaning for themselves and of treating didactics with suspicion (Lahm 2016: 30), which can go hand in hand with the beliefs that creativity cannot be taught and that fascination for one's field should be taken for granted; this might also help to explain why these issues are not mentioned extensively in the books.

Both the historical neglect of didactics and the dominance of non-experts appear to be changing, however, and a study ten years from now might yield very different results, as writing centers and teachers are gaining more influence on academics from other disciplines and the publishing industry. Observers from America point to the 'exponential growth' of German writing centers and scholarship, and stress that the US can actually learn from the central role the centers play in creating writing pedagogies and the way they make writing processes the focus of their research (Scott 2016: 3). Publishers are willing to publish books that provide background knowledge on academic writing for university teachers (Girgensohn and Sennewald 2012; Grieshammer et al. 2015), and rhetoric and composition experts get to write books on specific aspects of the world of academic writing, such as paraphrasing (Lange 2013), portfolios (Bräuer 2016), and short texts (Schindler 2011). It stands to reason that a scenario is possible in the near future whereby the major generalist primers a student in Germany can choose from will be authored by writing specialists and will thus take creativity into account. 
Currently, however, the phenomenon the basic findings of this article point to - a lack of focus on creativity in German guidebooks on research writing - is a reality. And the reasons stated above, while neither definitive nor exhaustive, highlight how the phenomenon is not benign or isolated from other aspects of the field of rhetoric, and therefore might help improve understanding of the challenges writing teachers and students in Germany are currently facing. 


\section{References}

Arnold, J., Poston, K., and Witek, K. (1999) Research Writing in the Information Age. Boston: Allyn and Bacon

Ballenger, B. (2012) The Curious Researcher: A Guide to Writing Research Papers. 7th edn. Boston: Pearson

Balzert, H., Schäfer, C., Schröder, M., and Kern, U. (2008) Wissenschaftliches Arbeiten: Wissenschaft, Quellen, Artefakte, Organisation, Präsentation. Witten: W3L

Booth, W. C, Colomb, G. C., and Williams, J. M. (1995) The Craft of Research. Chicago: University of Chicago Press

Bräuer, G. (2016) Das Portfolio als Reflexionsmedium für Lehrende und Studierende. 2nd edn. Opladen: Verlag Barbara Budrich

Brauner, D. J., and Vollmer, H.-U. (2004) Erfolgreiches wissenschaftliches Arbeiten: Seminararbeit Diplomarbeit Doktorarbeit. Sternenfels: Wissenschaft \& Praxis

Burke, K. (1974) The Philosophy of Literary Form: Studies in Symbolic Action. Berkeley: University of California Press

Carter, M. J. (2013) 'The Hermeneutics of Frames and Framing: An Examination of the Media's Construction of Reality'. SAGE Open 3 (2), 1-12

Charbel, A. (2006) Schnell und einfach zur Doktorarbeit: Der praktische Ratgeber für Studenten. 5th edn. Nürnberg: BW Bildung und Wissen

Clark, I. L. (2007) Writing the Successful Thesis and Dissertation: Entering the Conversation. Upper Saddle River: Prentice Hall

Clyne, M. (1987) 'Cultural Differences in the Organization of Academic Texts: English and German'. Journal of Pragmatics 11 (2), 211-247

Csikszentmihalyi, M. (1996) Creativity. New York: HarperCollins

Entman, R. M. (1993) 'Framing: Toward Clarification of a Fractured Paradigm'. Journal of Communication 43 (4), 51-58

Esselborn-Krumbiegel, H. (2002) Von der Idee zum Text: Eine Anleitung zum wissenschaftlichen Schreiben. Paderborn: Schöningh

Frank, A., Haacke, S., and Lahm, S. (2007) Schlüsselkompetenzen: Schreiben in Studium und Beruf. Stuttgart: Metzler

Franken, R. E. (1993) Human Motivation. 3rd edn. Pacific Grove: Brooks/Cole

Girgensohn, K., and Sennewald, N. (2012) Schreiben lehren, Schreiben lernen: Eine Einführung. Darmstadt: WBG

Gitlin, T. (2003) The Whole World Is Watching. Berkeley: University of California Press

Goffman, E. (1974) Frame Analysis: An Essay on the Organization of Experience. Boston: Northeastern University Press

Goshert, J. C. (2009) Entering the Academic Conversation: Strategies for Research Writing. Upper Saddle River: Prentice Hall 
Göttert, K.-H. (1999) Kleine Schreibschule für Studierende. München: Fink

Graff, G., Birkenstein, C., and Durst, R. (2014) 'They Say/l Say': The Moves that Matter in Academic Writing. 3rd edn. New York: Norton

Grieshammer, E., Liebetanz, F., Peters, N., and Zegenhagen, J. (2015) Zukunftsmodell Schreibberatung: Eine Anleitung zur Begleitung von Schreibenden im Studium. 3rd edn. Baltmannsweiler: Schneider Verlag Hohengehren

Haines, M. (2009) ABC der wissenschaftlichen Abschlussarbeit. Paderborn: Schöningh

Hall, S. (1982) 'The Rediscovery of "Ideology": Return of the Repressed in Media Studies'. in Culture, Society and the Media. ed. by Gurevitch, M., Bennett, T., Curran, J., and Woollacott, J. London: Methuen, 52-86

Harris, J. D. (1997). A Teaching Subject: Composition Since 1966. Upper Saddle River: Prentice Hall

Heimes, S. (2011) Schreiben im Studium: Das PiiP-Prinzip. Göttingen: Vandenhoeck \& Ruprecht

Kornmeier, M. (2008) Wissenschaftlich schreiben leicht gemacht: Für Bachelor, Master und Dissertation. Bern: Haupt

Krämer, W. (2009) Wie schreibe ich eine Seminar- oder Examensarbeit? 3rd edn. Frankfurt: Campus

Krajewski, M. (2013) Lesen Schreiben Denken: Zur wissenschaftlichen Abschlussarbeit in 7 Schritten. Köln: Böhlau

Kruse, O. (2007) Keine Angst vor dem leeren Blatt: Ohne Schreibblockaden durchs Studium. 12th edn. Frankfurt: Campus

Kuypers, J. A. (2009) Rhetorical Criticism: Perspectives in Action. Lexington: Lexington Press

Kuypers, J. A. (2009) 'Framing Analysis From a Rhetorical Perspective'. in Doing News Framing Analysis: Empirical and Theoretical Perspectives. ed. by D'Angelo, P., and Kuypers, J.A. New York: Routledge, 286-311

Kuypers, J. A. (2006) Bush's War: Press Bias and Framing of the War on Terror. Lanham: Rowman and Littlefield

Lahm, S. (2016) 'Stories We Live by: A Review of Writing Center Work in Higher Education in Germany'. in Akademisches Schreiben: Vom Qualitätspakt Lehre 1 geförderte Schreibprojekte. ed. by Knorr, D. Hamburg: Universität Hamburg

Lange, U. (2013) Fachtexte lesen - verstehen - wiedergeben. Paderborn: Schöningh

Nelson, T. E., Oxley, Z. M., and Clawson, R. A. (1997) 'Toward a Psychology of Framing Effects'. Political Behavior 19 (3), 221-246

Northey, M., and McKibbin, J. (2012) Making Sense: A Student's Guide to Research and Writing. 7th edn. Don Mills: Oxford University Press

Peterßen, W. H. (1999) Wissenschaftliche(s) Arbeiten: Eine Einführung für Schule und Studium. 6th ed. München: Oldenbourg

Pospiech, U. (2012) Wie schreibt man wissenschaftliche Arbeiten? Alles Wichtige von der Planung bis zum fertigen Text. Mannheim: Duden 
Preißner, A. (2012) Wissenschaftliches Arbeiten: Internet nutzen - Text erstellen - Überblick behalten. 3rd edn. München: Oldenbourg

Pyerin, B. (2001) Kreatives wissenschaftliches Schreiben: Tipps und Tricks gegen Schreibblockaden. Weinheim: Juventa

Reese, S. D., Gandy Jr., O. H., and Grant A. E. (eds.) (2010) Framing Public Life: Perspectives on Media and Our Understanding of the Social World. New York: Routledge

Ripple, R. E. (1999) 'Teaching Creativity'. in Encyclopedia of Creativity. vol. 2. ed. by Runco, M. A., and Pritzker, S. R. San Diego: Academic Press, 629-638

Roberts, C. M. (2010) The Dissertation Journey: A Practical and Comprehensive Guide to Planning, Writing, and Defending Your Dissertation. 2nd edn. Thousand Oaks: Corwin

Schindler, K. (2008) 'Wissenschaftliches Schreiben in Sprach und Kommunikationswissenschaft: Zwei Beispiele für schreibintensive Lehrveranstaltungen in den Geisteswissenschaften'. Zeitschrift Schreiben 17 May, 1-8

Schindler, K. (2011) Klausur, Protokoll, Essay: Kleine Texte optimal verfassen. Paderborn: Schöningh

Schindler, K., and Fischbach, J. (2015) 'Einleitung: Der Brennpunkt der Kontroverse'. in Zwischen Schule und Hochschule: Akademisches Schreiben. ed. by Schindler, K., and Fischbach, J. Zürich: Zeitschrift Schreiben, 7-10

Scott, A. (2016) 'Re-Centering Writing Center Studies: What U.S.-Based Scholars Can Learn from Their Colleagues in Germany, Switzerland, and Austria'. Zeitschrift Schreiben 28 November, 1-10

Siepmann, D. (2006) 'Academic Writing and Culture: An Overview of Differences between English, French and German'. Meta 51 (1), 131-150

Simonton, D. K. (2013) 'What Is a Creative Idea? Little-c Versus Big-C Creativity'. In Handbook of Research on Creativity. ed. by Thomas, K., and Chan, J. Cheltenham: Edward Elgar, 69-83

Skeat, W. W. (1893). An Etymological Dictionary of the English Language. Oxford: Clarendon Press

Stickel-Wolf, C., and Wolf, J. (2013) Wissenschaftliches Arbeiten und Lerntechniken: Erfolgreich studieren - gewusst wie! 7th edn. Wiesbaden: Springer Gabler

Swales, J. M., and Feak, C. B. (2012) Academic Writing for Graduate Students: Essential Tasks and Skills. 3rd edn. Ann Arbor: The University of Michigan Press

Theisen, M. R. (2005) Wissenschaftliches Arbeiten: Technik - Methodik - Form. 12th edn. München: Vahlen

Voss, R. (2010) Wissenschaftliches Arbeiten: ... leicht verständlich! Stuttgart: Lucius \& Lucius

Winter, W. (2005) Wissenschaftliche Arbeiten schreiben: Hausarbeiten / Diplom- und Magisterarbeiten / MBA-Abschlussarbeiten / Dissertationen. Frankfurt: Redline Wirtschaft

Wolfsberger, J. (2007) Frei geschrieben: Mut, Freiheit und Strategie für wissenschaftliche Abschlussarbeiten. Wien: Böhlau 